\title{
Coffee and Conservation: a Global Context and the Value of Farmer Involvement
}

\author{
STACY M. PHILPOTT* AND THOMAS DIETSCH†‡ \\ *Department of Ecology and Evolutionary Biology, University of Michigan, 830 N. University, Ann Arbor, MI 48109-1048, U.S.A., \\ email sphilpot@umich.edu \\ †School of Natural Resources and the Environment, University of Michigan, 430 E. University, Ann Arbor, MI 48109, U.S.A.
}

In a recent issue of Conservation Biology, Rappole et al. (2003) argued that promoting shade-grown coffee threatens some forest ecosystems (particularly highland pineoak forests) and discussed reasons why the shade coffee movement is misleading in terms of biodiversity conservation. Here, we argue that in the larger global agricultural context, and if promoted correctly, shade coffee does not present a significant threat to forest conservation but instead may advance conservation goals. Furthermore, we present an alternative way for conservationists to reduce future threats from shade-grown coffee via linkage of rigorous shade certification with fair-trade certification programs.

Conservation value is frequently measured by assessing species richness or number of forest species inhabiting disturbed areas. Recently, much attention has been focused on measuring biodiversity loss across agricultural intensification gradients, particularly in coffee agroecosystems. Rustic or traditional coffee farms conserve a large number and proportion of forest species (e.g., Perfecto et al. 1996; Greenberg et al. 1997), and differences in shade management strongly affect species richness (Perfecto \& Snelling 1995; Calvo \& Blake 1998; Perfecto \& Vandermeer 2002). However, some species are lost even with the smallest habitat modifications, and species composition in shade-coffee farms is not identical to that of forest (Rappole et al. 2003).

This said, shade-coffee production, in Mexico in particular, may not present a significant threat to forests. Much forest habitat (up to $76 \%$ of rain forest and $50 \%$ of pine-oak forest) within the elevational band optimal for coffee production has already been displaced or affected by some form of coffee agroecosystem (Moguel \& Toledo 1999). Additionally, one forest specialist at risk as assessed

¥Current address: Smithsonian Migratory Bird Center, National Zoological Park, 3001 Connecticut Avenue, NW, Washington, D.C. 20008, U.S.A.

Paper submitted April 1, 2003; revised manuscript accepted June 18, 2003. by Rappole et al. (2003), the Golden-cheeked Warbler (Dendroica chrysoparia), generally occurs from 1500 to $3000 \mathrm{~m}$ in Chiapas (Howell \& Webb 1995), above the ideal coffee-growing zone of 600-1200 m (Moguel \& Toledo 1999). Thus, the risks of converting pine-oak forests to coffee production may exist at forest margins, but the prime agricultural threats probably stem from maize and cattle production, which extend to higher elevations than coffee.

Loss of species richness in highly shaded coffee farms is minimal compared with the enormous losses experienced with other forms of agricultural modification. The few studies examining differences in species richness between shade coffee and other agricultural habitats document lower species richness in more intense systems such as active pasture or sugarcane (Borrero 1986; Terborgh 1989; Greenberg 1994; Petit et al. 1999). Furthermore, researchers finding no differences between shade coffee and other agricultural systems have not reported on the vegetational diversity or structure of the agricultural habitats they examined (Ricketts et al. 2001). Thus, when coffee plantations are compared with other agricultural choices, shade coffee may not be as risky as it seems.

The potential risks of shade coffee production are not to be ignored because coffee is grown coincident with some of the world's biodiversity hotspots (Hardner \& Rice 2002) and may overlap with key forest habitats (Greenberg et al. 1997). In a global conservation context, however, the effects of shade coffee pale in comparison to other types of agricultural conversion. In northern Latin America (Mexico, Central America, the Caribbean, and Colombia), permanent pasture covers approximately 2.2 billion ha (37\% of total land), whereas all coffee production covers only 3.6 million ha ( $0.6 \%$ of total land), $<2 \%$ of area dedicated to pasture (Food and Agriculture Organization 2002).

In the past 3 years, coffee prices (determined by the commodities market of the New York stock exchange) reached lows of U.S.\$0.42/1b (Food and Agriculture 
Organization 2002), prices not even meeting farmers' production costs (Perfecto el al. 1996). Low prices, stemming from global economic policies and coffee overproduction, have resulted in widespread environmental and social disasters (Gresser \& Tickell 2002). Many small farmers in Latin America have abandoned their coffee farms and migrated north. Others have intensified production toward sun management, attempting to increase yields, or have converted shade coffee farms to cattle pasture or illegal crops. Reportedly, in Colombia an estimated 1000 of 560,000 coffee farms had been converted to coca and poppy production by mid 2001 (Wilson 2001). Although figures of conversion rates are unavailable for Mexico, we have witnessed intensification of shaded farms to sun production or to corn milpas there, where small producers represent approximately $95 \%$ of coffee producers $(65.5 \%$ of total production area) (Rice \& Ward 1996). Low coffee prices, affecting small farmers more deeply, will thus enormously affect conservation efforts of any kind in the region.

How can consumers and conservationists ensure that ecologically friendly coffee production remains an alternative while responsibly educating the public? Rappole et al. (2003) argue that those promoting shade coffee may not distinguish between differences in shade management or may mislead buyers by equating shade-coffee biodiversity with natural forests. However, this is precisely why rigorous shade-certification programs are necessary. It is not true, as asserted by Rappole et al. (2003), that both extremes of shade coffee-rustic and highly pruned monospecific shade-qualify as shade coffee. The two existing certification programs, Bird Friendly Coffee ${ }^{\circledR}$ from the Smithsonian Migratory Bird Center and Eco-OK of the Rainforest Alliance, require a diverse canopy and certain levels of structural diversity. For example, Mas and Dietsch (2003) found one plantation with shade composed primarily of Inga and a few other species that did not qualify as shade coffee even under the Eco-OK label, the more lenient of the two.

Rappole et al. (2003) seem to underestimate the potential of conservation-oriented agriculture. They ask, "What sort of certification process will assure that the funds generated to support shade coffee actually go toward tropical habitat conservation?" In the context of the global economic coffee crisis and its conservation consequences, we believe a more appropriate question to ask is "What sort of certification process will assure that funds go directly to farmers as an incentive for maintaining shade coffee farms?" One promising way is to link rigorous shade-certification programs incorporating organic certification (i.e., Bird Friendly Coffee ${ }^{\circledR}$ ) with fair-trade certification, thus meeting the goals of both conservationists and farmers. According to Transfair USA (http://www.transfairusa.org), the largest fair-trade coffee certifier for U.S. consumption, fair-trade certification offers price premiums, advance payment, and loans to small farmers, ensuring they can make a living. Farmers are currently guaranteed $\$ 1.26 / 1 \mathrm{~b}$, and $\$ 1.41 / \mathrm{lb}$ for certified-organic coffee, or at least 5 and 15 cents above market prices. Additionally, shade and organic certification programs are prohibitively expensive for most coffee growers (Gobbi 2000), whereas fair-trade certifiers, like Transfair, pay the costs of farm visits. Currently, however, fair-trade certifiers, although promoting environmentally friendly methods, do not require shade or organic certification.

Many conservation approaches do not connect conservation and social justice. We suggest, however, that a strong linkage between organic, shade, and fair-trade certification programs may provide one long-term conservation strategy in coffee growing regions. Unifying certification programs will also alleviate some consumer confusion between different types of sustainable coffees. It is true that only the most rigorous shade-certification programs preserve relatively high levels of biodiversity and forest species, in particular. But unless shade standards are linked to price premiums for coffee producers, not for conservation organizations or certification agencies, these programs will ultimately fail, and specialists such as the Golden-cheeked Warbler will be lost when farmers face the choice of clearing forest or starvation.

We agree that shade coffee may not preserve some highly specialized forest species, but given that $95 \%$ of the Earth is covered in agriculture and other human-modified ecosystems (Pimentel et al. 1992), incorporating agricultural systems and people that manage them is crucial to the success of any conservation effort. Shade coffee may provide a refuge for many species at the landscape level, because embedding forest fragments in less intensely managed agricultural landscapes may be correlated with higher richness or less patch isolation (Fahrig 2001; Ricketts 2001; Vandermeer \& Carvajal 2001; Steffan-Dewenter 2002).

Rappole et al. (2003) discuss one potential problem with the shade-coffee campaign: creation of incentives to convert forest to shade coffee. This, however, is not an insurmountable problem. To ensure that farmers are not tempted to convert forest to shade coffee, certifiers should prohibit certification of farms converted recently (within 10 years). In addition, rigorous shade criteria should be amply circulated among extension agents to deter clearing of forest understory for coffee. Furthermore, shade-certification programs must address the importance of forest fragments, giving credit to farmers for preserving adjacent forest fragments. Most important, certification must include financial incentives for coffee producers to maintain shaded farms because without incentives, and faced with economic hardship, farmers may convert their lands to sun coffee, pasture, or swidden agriculture, requiring that they cut more forest. By including coffee producers in conservation plans via linkage of organic, shade, and fair-trade certification programs, 
scientific and conservation communities may better meet conservation goals in regions where coffee production is a major livelihood.

\section{Acknowledgments}

We thank I. Perfecto and J. Vandermeer for comments on the manuscript.

\section{Literature Cited}

Borrero, J. H. 1986. La sustitucion de cafetales por caturales y su efecto negativo sobre la fauna de vertebrados. Caldasia 15:725-732.

Calvo, L., and J. Blake. 1998. Bird diversity and abundance on two different shade coffee plantations in Guatemala. Bird Conservation International 8:297-308.

Fahrig, L. 2001. How much habitat is enough? Biological Conservation 100:65-74.

Food and Agriculture Organization (FAO). 2002. Agricultural Production Statistics. FAO, Rome. Available from http://apps.fao.org/ (accessed March 2002).

Gobbi, J. A. 2000. Is biodiversity-friendly coffee financially viable? An analysis of five different coffee production systems in western El Salvador. Ecological Economics 33:267-281.

Greenberg, R. 1994. Phenomena, comments, and notes. Smithsonian 11:24-26.

Greenberg, R., P. Bichier, and J. Sterling. 1997. Bird populations in rustic and planted shade coffee plantations of Eastern Chiapas. Mexico. Biotropica 29:501-514.

Gresser, C., and S. Tickell. 2002. Mugged: poverty in your cup. Oxfam International, Washington, D.C.

Hardner, J., and R. Rice. 2002. Rethinking green consumerism. Scientific American 286:88-95.

Howell, S. N. G., and S. Webb. 1995. A guide to the birds of Mexico and Northern Central America. Oxford University Press, Oxford, United Kingdom.

Mas, A. H., and T. V. Dietsch. 2003. An index of management intensity for coffee agroecosystems to evaluate butterfly species richness. Ecological Applications 13:1491-1501.
Moguel, P., and V. M. Toledo. 1999. Biodiversity conservation in traditional coffee systems of Mexico. Conservation Biology 13:1121.

Perfecto, I., R. A. Rice, R. Greenberg, and M. E. VanderVoort. 1996. Shade coffee: a disappearing refuge for biodiversity. Bioscience 46:598608.

Perfecto, I., and R. Snelling. 1995. Biodiversity and the transformation of a tropical agroecosystem: ants in coffee plantations. Ecological Applications 5:1084-1097.

Perfecto, I., and J. Vandermeer. 2002. Quality of agroecological matrix in a tropical montane landscape: ants in coffee plantations in southern Mexico. Conservation Biology 16:174-182.

Petit, L. J., D. R. Petit, D. G. Christian, and H. D. W. Powell. 1999. Bird communities of natural and modified habitats in Panama. Ecography 22:292-304.

Pimentel, D. A., U. Stachow, D. A. Takacs, H. W. Brubaker, A. R. Dumas, J. J. Meaney, J. A. O'Neil, D. E. Onsi, and D. B. Corzilius. 1992. Conserving biological diversity in agricultural/forestry systems. BioScience 42:354-362.

Rappole, J. H., D. I. King, and J. H. Vega Rivera. 2003. Coffee and conservation. Conservation Biology 17:334-336.

Rice, R., and J. Ward. 1996. Coffee, conservation, and commerce in the Western Hemisphere. White paper 2. Smithsonian Migratory Bird Center, Washington, D.C.

Ricketts, T. H. 2001. The matrix matters: effective isolation in fragmented landscapes. The American Naturalist 158:87-99.

Ricketts, T. H., G. C. Daily, P. R. Ehrlich, and J. P. Fay. 2001. Countryside biogeography of moths in a fragmented landscape: biodiversity in native and agricultural habitats. Conservation Biology 15:378388.

Steffan-Dewenter, I. 2002. Landscape context affects trap-nesting bees, wasps, and their natural enemies. Ecological Entomology 27:631637.

Terborgh, J. 1989. Where have all the birds gone? Princeton University Press, Princeton, New Jersey.

Vandermeer, J., and R. Carvajal. 2001. Metapopulation dynamics and the quality of the matrix. The American Naturalist 158:211220.

Wilson, S. 2001. Coca invades Colombia's coffee fields: falling prices push farmers to plant illegal crops, threatening U.S. drug war. The Washington Post, 30 October: A17.

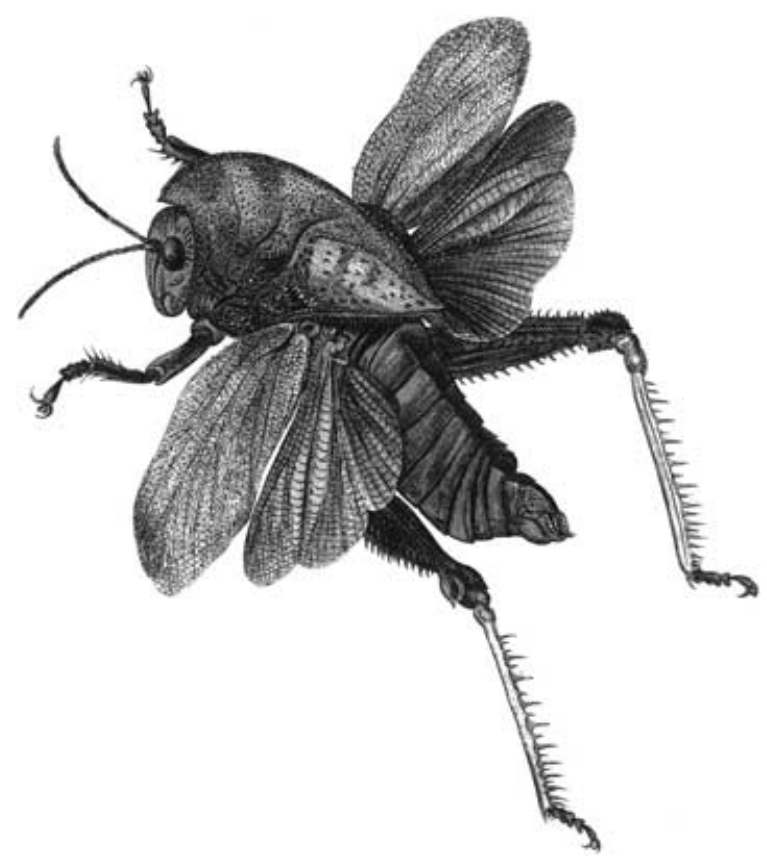

